\title{
Political Corruption and Presidential Elections, 1929-1992
}

\author{
Tim Fackler and Tse-min Lin \\ Department of Government \\ University of Texas at Austin \\ Austin, TX 78712 \\ (512) 471-5121 \\ Internet:
}

Fackler: fackler@jeeves.la.utexas.edu

Lin: gvce470@utxvm.cc.utexas.edu

An early version of this paper was delivered at the annual meeting of the Midwest Political Science Association in Chicago, IL, April 14-16, 1994. Authors are listed alphabetically and share equal responsibility for the arguments presented here. Thanks for insightful comments and criticisms on an earlier draft but no blame for any errors of commission or omission are due Frank Baumgartner, David Braybrooke, Dean Burnham, Michael Johnston, Brian Roberts, and Bat Sparrow. 


\section{Political Corruption and Presidential Elections, 1929-1992}

We develop an aggregate model of the presidential vote based on the appropriation of political as well as economic information by a rational voter. We argue that, depending upon historical context, information about political corruption is relevant to individual, and hence aggregate, vote choice. In preindustrial, community-oriented machine politics, the rational voter exchanged votes for particularistic benefits. As the social and political perspective shifted to a universalistic standard, information about corruption has become for him or her one of the criteria by which to evaluate the performance of the incumbent party. By including information about corruption alongside information about the economy, our model significantly improves upon conventional economic voting models in explaining post-New Deal presidential election outcomes. 


\section{Introduction}

Political corruption of one kind or another has recently figured prominently in the news from Washington and around the world. In the United States, President Clinton is being charged with financial improprieties and cover-up involving his past dealings with the Whitewater development project. The outcome of recent elections in Italy turned upon widespread official wrongdoing. Radical political changes in the former Soviet Union were in part spurred by rampant bureaucratic corruption. In 1993, after almost 40 years in power, Japan's Liberal Democratic Party lost control of the government amid revelations of rampant corruption and the prime minister of the successor coalition resigned in early 1994 in the face of similar charges. Political corruption can and often does play an important role in politics and policy making in the United States and around the globe. However, as information that plays a prominent role in politics and political change, it is rarely given serious consideration by students of American politics and, particularly in the context of elections, we know relatively little about its effects.

Conventional longitudinal studies of elections concentrate on the effects of economic variables. In most cases, the only political variables included in economic voting models (Fair 1978, 1982, 1988) are dummy variables indicating the status of individual or partisan incumbency or popularity variables that may help predict but do little to explain the vote (Lewis-Beck and Rice 1992; Abramowitz 1994). While economic variables are undeniably important, a more complete model should take account of other political variables, in particular negative information available to voters. In the New Deal party system and after, we argue, voters incorporate negative information about the behavior of public officials in their vote choices. Information about political corruption is especially important in this regard. The impact of Watergate on the 1976 election was obvious, but, to various degrees, such concerns are constantly raised over the course of almost all administrations. To capture this process we develop a longitudinal measure of information about political corruption based on counts of relevant news stories. We employ this measure to investigate the effects of information about political corruption along with the effects of economic variables on presidential election outcomes. Our results show that, since the 1932 election, information about political corruption has had a statistically significant and substantial negative effect on the incumbent party's presidential vote share. 


\section{The Changing Universe of Political Corruption}

What do we mean by political corruption? Political corruption commonly refers to a variety of undesirable or unlawful public-office-related acts by political actors (Heidenheimer, Johnston, and LeVine 1989, 8-9). Such acts may involve the pursuit of public office by a candidate or the use of public office by an official, but any political actor, including voters and citizens, may engage in corrupt acts. By defining corruption as an intentional act by political actors, we do not mean to overlook the republican understanding of the problem as a general loss of civic virtue (Euben 1989). On the contrary, in a certain historical context (viz. machine politics), corruption is more a problem of structure than of agency. Even for the postNew Deal period for which we present our major empirical findings, we do not consider corruption as solvable by removing "a few miscreants" from positions of authority (Euben 1989, 242). By "corruption" in this study we mean available information regarding different types of acts (perhaps no more than alleged) by political actors. Such information, especially as it becomes available to a wider audience, has political effects that, we contend, depend on the changing social and political perspective of the American voter. While we assume that voters are rational, the relation between voters' information and their decisions need not be uniform over time. ${ }^{1}$ Indeed, we argue that the flow of information and the nature of individual voters' calculations about corruption shifted in the early twentieth century.

Information about various kinds of political corruption has appeared throughout American history. Any systematic aggregate relation, however, between corruption and the political system (elections in particular) has been elusive. Official corruption of one kind or another has been charged of almost every presidential administration (Woodward 1974). The issue seems to have come to very little in most cases, although some cases have been spectacular. The administration of Democrat James Buchanan at the beginning of the Civil War party system seems to have marked the low point in public ethics in the ante-bellum period. The Grant administration, in the middle of the same party system, is often reputed among the most corruption-riven administrations in American history. Both candidates, Hayes and Tilden, in the ensuing disputed election of 1876 campaigned against corruption though the election itself was marred by charges of vote fraud. Fierce national party competition in the late nineteenth century produced instances aplenty of electoral corruption. But the ballot reforms of the late nineteenth century along with increased federal and state regulation of politics diminished-or at least altered-the opportunities for ballotrelated corruption (Burnham 1965, 1974, 1986; Converse 1972; Cox and Kousser 1981; Allen and Allen 1981; Mayfield 1993). ${ }^{2}$ 
Through much of the period 1865-1929, information about political corruption was largely local and intimately connected with machine politics and reform (see, for instance, Steffens 1931; Riordan 1994; Gosnell 1968; Merton 1957; Banfield and Wilson 1963; Wolfinger 1972; Bridges 1984; Grimshaw 1992). While national scandals captured some public attention, such corruption on high nonetheless tended to have deep local roots in the customs houses, revenue offices, and myriad outposts of local public authority and entered voters' calculations differently than such information does today. Machines operated locally, filtering information and organizing-by means both fair and foul-the political, economic, and social lives of the inhabitants of the cities in which they arose, sometimes shaping national political outcomes. More importantly, however, political machines reflected the predominance in this period of the community-oriented end of what Hays (1967) calls the "community-society" continuum in American political life. Building upon "personal, community, face-to-face contacts" as opposed to "impersonal, mass relationships in the wider society," political organizations consistently commanded the loyalties of large blocs of voters despite the concerted attention of political reformers in the late nineteenth and early twentieth centuries (Hays 1967, 154). Reformers gauged machine corruption against new universalistic standards evident in the new functional and economic institutions (e.g., the new corporations, professions, mass media, and government bureaucracies) linking or supplanting the myriad "island communities" (Wiebe 1967) then at the rapidly changing core of American life. But as long as voters received information primarily through community institutions and perceived their political world primarily in community-oriented terms they preferred organized local mechanisms of decision making (such as machines) that directly and materially benefited them and their community and helped them hold to ways of life increasingly threatened by the alien sources of information, impersonal mechanisms of decision making, and often dubious benefits of encroaching mass industrial society.

From the emerging perspective of those searching for order in mass society (e.g., the perspective of the reformer, the corporate manager, the middle class professional, the muckraker, or the new civil servant) substitution of society-oriented for community-oriented ways of life, universalistic for particularistic standards, could not be more rational, necessary, and right. Political reform helped to create new social institutions, alter political perceptions, and introduce preferences for more centralized and expansive mechanisms of decision making. For instance, ballot reform legislation in the 1880s and 1890s, followed by reforms such as the initiative and referendum, helped remove control of elections from local party organizations to the state and helped reduce perceptions of the vote as negotiable. At their height (c. 1900-1912), the muckrakers were adding the faults of the major new industrial combines to those of the older "shame of the cities," urban machines. By the 1920s, old forms of community were disappearing, retreating, assimilating, or otherwise 
succumbing to modernizing mass society (Cohen 1990), and perceptions of political corruption were in transition. Best known in these years, the Teapot Dome affair embroiled, among others, members of Harding's cabinet, the finances of the Republican national committee, a leading Democratic presidential contender, and leading proponents of national conservation policy (Noggle 1962). Even traditional disputes-disputes about the role of money in and the validity of elections-were changing. The switch to direct election of Senators, state regulation of elections, and early federal efforts to regulate campaign finances combined to help force the Senate, rather than local parties or state legislatures, to consider before a national audience the validity of the outcomes of bitterly fought primaries in Illinois, Pennsylvania, and elsewhere in 1926. With the beginning of the New Deal party system, the "old machine" did not wither away, ballot abuses persisted (particularly in the South), and accounts of graft, bribery, and a host of other corrupt activities none too different from those of earlier years continued to surface. But as impersonal society, national in scope, came to dominate political life, as voters were exposed to new information, accepted universalistic standards, and were increasingly estranged from community, they came to perceive information about corruption as evidence of random acts of official greed without benefit to them. Under this "new machine" it is rational for voters to punish corruption about which they have any information as during the 1950s (in both the Truman and Eisenhower administrations), the Watergate era of the 1970s, and at the end of the Reagan and during the Bush administrations.

We can add to this account much that might seem only to add to the idiosyncrasies of the historical record (see Nice 1983; Meier and Holbrook 1992; Johnston 1983; Peters and Welch 1980). Our point, however, is that choices rational in one context need not be in another context. ${ }^{3}$ In our account, the period 1865-1929, spanning two party systems, was characterized by voters' preferences for community institutions, parochial perceptions, and local decision making mechanisms. Information about political corruption arrived through local channels along with material benefits both often supplied by the individuals and organizations labeled corrupt. Given material inducements and the nature of available information, it was logical for voters to ignore, tolerate, or discount information about corruption, especially information from outside their community. By 1929, however, changes in community structures and values, crystallized under the force of the Great Depression, were substantial enough in scope that we are justified in speaking of a new political universe, one in which information flows to voters primarily through mass media and voters have few community-oriented reasons to ignore, discount, or tolerate negative political information.

We do not mean to suggest modern electoral responses to political corruption bear no relation to earlier responses. Voters still expect public officials to serve their interests. Rather, the efficacy 
of the national government became a real concern on a grand scale for ordinary people with the Great Depression and the New Deal. National government took on enormous new roles, but it would be held to account as well. Federal officials, much less able than local machine politicians to trade personal material benefits for partisan support, would have to contend with closer scrutiny of their uses of office, particularly when promised policies do not deliver. Thus, charges against a candidate swayed and still sway voters, though they evaluated such charges differently in a more community oriented period. Such charges now predictably cost public officials votes or even office in a more cosmopolitan society (Rundquist, Strom, and Peters 1977; Peters and Welch 1980).

\section{Information, Political Corruption, and Voter Choice}

We have suggested that conditions of voters' processing of economic and political information, particularly information about political corruption, substantively changed by 1929. This is contrary to and, we believe, more plausible than Fair's (1978) implicit assumption that the informational context of voters' evaluations has been constant throughout most of the twentieth century (and probably earlier). Altered social, political, and economic contexts gave new information new weight in voters' decisions. As Beck (Beck 1986, 262) observes, "context sets the boundaries of the choice situation." Since we are developing an aggregate voting model, however, we need to make clear, as Fair does (1978), the underlying model of individual voting behavior, one that can incorporate information about political corruption.

Rundquist, Strom, and Peters (1977) developed theoretical explanations for what they called "corruption voting," i.e., voting for corrupt candidates. Although we are not specifically concerned in this paper with electoral support for politicians who are themselves involved in corruption, the theory of corruption voting as they laid it out is important for our understanding of political corruption as information processed by voters in making their electoral choice.

In answering the question why corrupt officials often are not reprimanded at the polls, Rundquist, Strom, and Peters first criticized the incompleteness of two basic explanations: the ignorant voter theory and the material inducement theory. The ignorant voter theory, which claims that information about corruption is often concealed from or otherwise unavailable to the voter, is incomplete because the availability of information is only a necessary but not a sufficient condition for the voter to vote down corrupt politicians. As such, the theory does not explain corruption voting by informed voters. Furthermore, as they point out, because of competition, information about 
corruption is often discounted during an election.

Unlike the ignorant voter theory, the material inducement theory does not assume that voters lack information about corruption. On the contrary, one may even say that the voter is a part of the corruption: politicians provide particularistic material inducements in exchange for electoral support. This type of explicit exchange was prevalent in the heyday of political machines. Although it illustrates the insufficiency of the ignorant voter theory, the material inducement theory is itself incomplete because, as we argued above, the historical community context in which organized corruption flourished no longer exists: it disappeared under the pressures of technological and societal changes.

Rundquist, Strom, and Peters' alternative explanation, based on the spatial theory of voting (Davis and Hinich 1966), is that corruption voting by informed voters in the absence of material inducements can best be understood as "implicit trading" between a rational voter and a corrupt candidate whose policy positions are closer to those of the voter than his competitor's positions. They assert that information about corruption should not be considered the sole determinant of vote choice: its effect has to be balanced by other considerations, in particular policy preferences. The possibility of "trading" corruption-explicitly for material inducements or implicitly for preferred policies-implies that the voter (if not Rundquist and his collaborators) may view information about corruption as more than an intangible "valence dimension" in the now full-fledged spatial theory of voting (Enelow and Hinich 1984). Like a corrupt politician who trades an increase in his expected percent of the vote in return for an increase in personal income (Rose-Ackerman 1978, 213; Rundquist, Strom, and Peters 1977, 957), a "corruption voter" trades information about corruption for policy preferences.

If a theory of corruption voting that ignores such implicit trading is incomplete, a rational choice model of voting that ignores the effect of information about corruption on vote choice-our concern in this paper-is also lacking. Only rarely in presidential elections has a candidate been personally the object of corruption charges. This does not mean, however, that information about political corruption is irrelevant. In the economic theory of voting, "a voter evaluates the current pronouncements and past performances of the competing parties, forms from this evaluation an expectation of her or his future utility under each party, and votes for the party that provides the maximum expected future utility" (Fair 1978, 159). According to this theory, voters are selfinterested and well informed, they only have to look back a year or two in judging the economic performance of an administration, and they evaluate economic performance in terms of changes in, 
rather than levels of, economic activity. Nothing in this economic theory, however, prevents voters from incorporating information about corruption in their evaluation of the incumbent party and in their assessment of their expected future utility under each party.

In the New Deal party system and after (1929-1992), we argue, voters still have a distinct and uniform interest in demonstrations that public officials and candidates are serving their interests just as they did in the earlier more communityoriented period. Since, in a society-oriented world in which political decision making is concentrated in the upper levels of the political system, it is no longer generally legal or acceptable for voters to expect or accept direct material inducements from politicians, voters obtain demonstrations of public officials' services now largely through mass media reports about the state of the economy, the behavior of public officials, and the like. While it may not be rational for a voter to seek out full information about officials' conduct, a voter will take account of it, particularly when it is subsidized since officials make universalistic valueallocating decisions that affect people's economic life. Estranged from community and isolated in impersonal mass relations, the voter takes care of his pocketbook more than ethnocultural or ethnoreligious ties (Lin 1993a). For such a voter, we contend, it is rational to evaluate the incumbent party's performance not only with respect to the economy but with respect to information about corruption. Corruption under the political machine involved organized efforts by self-interested officials that, at least partially, served the community, but now it involves mostly random acts by narrowly self-interested officials who return nothing to the public. To secure her pocketbook, it is thus rational for the voter to make sure that officials are working primarily for her, not for their own or others' interest. And elections are the primary means by which the voter can exercise control. Information about corruption, if it is in any degree credible, suggests to the voter that leaders are not keeping up their end of the bargain. Thus, to the voter's assessments of the incumbent party's economic performance in the conventional rational choice model of voting, we add information about corruption.

By phrasing our theory in terms of rational choice, we do not preclude the "valence" component of information about corruption. It is not self-contradictory (and hence irrational) for the voter to view corruption as a matter of morality or civic virtue, while at the same time seeing it as a threat to his economic well-being. Concerns about values, which many believe to be lost in the craze for modernity, are finding their way back to public life in the era of post-materialism (Inglehart 1990). As the impact of economic factors on voters' choice is saturating (Lin 1993a), we believe that the republican understanding of corruption only reinforces the voters' rational assessment against an incumbent party whose leadership fails to contain corruption. The modern era is considered the 
era of presidential government. The president is responsible for the state of the economy, and he also has primary responsibility not only for the efficacy but also the honesty and trustworthiness of national government. Whether or not information arises about the president directly, voters take account of information about political corruption, weakening their support for the incumbent president and his party. The more information that voters accumulate over the course of each term, the more their support of the incumbent party, as measured in the share of two-party vote, decreases.

In sum, voters in the modern period upon which we focus believe that national government affects their lives. Political leaders can provide few direct material inducements to obtain voter support nor do they organize the flow of political information as in the past. ${ }^{4}$ Voters depend heavily now upon information from many new (often "objective") sources rather than upon parties or upon the leaders' provision of direct material benefits in making their voting decisions. If available information indicates leaders are improving the state of the economy and that they are otherwise trustworthy, rational voters will support them, otherwise not. Thus, we can treat aggregate economic indicators such as the changes in real per capita disposable personal income as evidence to voters of whether leaders are serving their interests. Evidence that they are not will increase voters' reluctance to return them to office. Information about political corruption also provides voters evidence, negative evidence, about how well leaders are serving their interests. Though aggregate models of elections have focused primarily on economic information, we can and should incorporate in our models other, particularly political, information as well.

\section{A Measure of Information about Political Corruption}

Until relatively recently no ready source of political corruption data existed. Surveys too infrequently and inconsistently asked relevant questions to be of much use. The Justice Department, however, began to track indictments and convictions under federal anti-corruption statutes beginning in the early 1970s. A number of the studies employ this data, primarily as the dependent variable (e.g., Johnston 1983; Meier and Holbrook 1992). Peters and Welch (1980) construct another measure, again used as the dependent variable, covering the period 1968-1978. It incorporates all charges of corruption levied against candidates in Congressional elections during that period. No datasets, to the best of our knowledge, reach back in time before 1968. Thus, any long-term assessments of the causes and effects of political corruption have depended primarily on traditional historical methods. 
In this study we employ a measure of information about political corruption compiled from the Reader's Guide to Periodical Literature (RG). The entire set consists of a count of articles about political corruption and cross-referenced subtopics spanning over 100 years (1890-1992). The RG has, under the key word heading "Politics, Corruption in," sampled U.S. serial publications each year since 1900. A special volume covering the years 1890-1899 was produced in 1944. At the end of the subject listing are related key word headings also incorporated in the compilation for a total of 21 different headings over the entire period. Several have been continuously used, notably the primary one given above and "Political Ethics."

As our earlier discussion makes clear, the universe of information about political corruption has changed over time. Traditional historical methods are useful in describing such changes. The time series techniques we employ permit greater precision in describing and explaining historical processes. Applications of time series techniques, however, tend toward "ahistoricism" (Isaac and Griffin 1989). They separate theory from history, employ ahistorical conceptions of time, and privilege statistical over social and political theory. To account for historically contingent factors and thus to move closer to historical "actuality" in our time series models of presidential election outcomes, we examine data only for the period since 1929.

For each year we sum all articles from all primary and relevant secondary cross-referenced categories. To control for a roughly linear trend in the number of periodicals the RG indexes, we divide the yearly number of articles by the number of periodicals indexed by the RG that year to obtain a measure of stories per periodical per year. Figure 1 presents a time plot of this measure. In applying this measure to presidential elections we modify it slightly to capture the accumulation of information over the four years of each presidential term as described in Appendix 1.

(Figure 1 about here)

As the plot indicates, there are recognizable peaks and plateaus. The late 1980s and early 1990s show several peaks where Wedtech, the HUD scandals, and various other affairs in the late Reagan administration came to light. In particular, between 1989-92 concerns about political ethics figured prominently, notably the HUD and Keating Five S\&L affairs and the displacement of Jim Wright early in this period. These tailed off in the last years of the series to be replaced by information about, among other things, Sununu's use of office and the personal banking practices of members of the House, BCCI, and an increasingly explicit anti-incumbency theme. The Iran-Contra affair is notably absent from the data. While some might argue that it ought to be included, the RG 
did not index it under political corruption or a cross-indexed category. The editors of the RG seem to have treated it primarily as a serious dispute about national security, rather than as a matter of political ethics, personal gain, or some other kind corruption. We follow RG practice in our coding. ${ }^{5}$ Moving further back along the plot, the Watergate period in the mid-1970s, not surprisingly, is the most distinctive peak. A crest in the early 1950s and activity through the decade involves a series revelations through late Truman administration and into the Eisenhower administration. A plateau through the 1930s represents a series of smaller affairs mostly related to the administration of various New Deal programs. A small, though sharp peak in the mid-1920s and some activity thereafter until about 1930 is linked to Teapot Dome. And a rough plateau from 1890 until about 1914 captures Progressive era activity (with political muckraking dominating the period from about 1900 to 1914).

As further tests of our argument that the post-1929 period differs from the pre-1929 period and thus of our decision to begin our study with the 1932 election we conducted a simple difference-ofmeans test and "moving correlation" analysis (Isaac and Griffin 1989) comparing the two periods. For the measure described above we are able to reject at the $p \leq .05$ level the null hypothesis that the means are equal. Though the effect is probably largely due to information about Watergate and a collection of concerns in the late 1980s, the significantly higher mean for the later period lends some support to our arguments that the 1932 election marks a change of pattern in the flow of information about corruption. Figure 2 presents the results of a moving correlation analysis employing a ten election "window," relating incumbent presidential party vote to our measure of information about corruption. With so few degrees of freedom it is not very sensible to carry out statistical significance tests for correlation coefficients at the conventional level, but the trend is unmistakably consistent with our arguments that the electoral effect of information about corruption has undergone a critical shift with the change in the American political universe in the beginning of the New Deal era.

\section{(Figure 2 about here)}

We also conducted difference-of-means tests the results of which demonstrate the validity of our data. For the 1929-1992 period, we were able to reject at the $p \leq .05$ level the null hypothesis that corruption information bears no relation to partisan control. The mean for years in which the Republican party occupies the presidency is almost double the mean for Democratic administrations, though the standard deviation of the former is considerably larger. This result is consistent with some writers' argument that periods of particularly strong corruption concerns coincide with 
Republican administrations (Manheim 1976; Philips 1990). Nice (1983) also found no relation between political corruption and Democratic party dominance for the period beginning from the 1970s. In addition, we were able to reject at the $p \leq .06$ level the null hypothesis that, for the 1929-1992 period, divided government is unrelated to a difference in means. The mean value of our corruption measure during divided government is about double that during unified government, though again the standard deviation of the former is large. This result accords with arguments that corruption is inversely related to party competition (Rose-Ackerman 1978; Nice 1983; Meier and Holbrook 1992).

\section{The Electoral Relevance of Corruption as Information}

To test our argument that the processing of information about political corruption is statistically relevant to electoral choice, we first present a null model in which the electorate appropriates information only about economic conditions and incumbency status. Our baseline model is similar to the conventional economic voting model (Fair 1978, 1982, 1988) with notable modifications:

$$
V_{t}=\alpha_{1}+\alpha_{2} \cdot P_{t} \cdot I_{t}+\alpha_{3} \cdot P_{t} \cdot \Delta D P I_{t}+\alpha_{4} \cdot P_{t} \cdot\left(\left|\Delta C P I_{t}\right|\right)^{2}+\alpha_{5} \cdot P_{t} \cdot\left(D C_{t}\right)^{2}+u_{t}
$$

where $V_{t}$ is the Democratic share (in percentage) of the two party vote in presidential election year $t(t=1932,1936, \ldots, 1992) ; P_{t}$ is a dummy variable representing the incumbent party ( 1 for the Democratic and -1 for the Republican); $I_{t}$ indicates personal incumbency ( 1 if the incumbent president is running for reelection and 0 if not); $\triangle D P I_{t}$ is the annual growth rate in per capita disposable personal income; $\left|\triangle C P I_{t}\right|$ is the annual inflation/deflation rate based on the consumer price index; and $D C_{t}$ is the duration (in presidential terms) the incumbent party has been in control of the presidency. These measures are discussed at greater length in Appendix 1.

The interaction of $P_{t}$ with all independent variables is used to adjust the sign of the coefficients such that the effect is directed toward the incumbent party. As in the conventional model, we postulate positive effects for personal incumbency and growth in personal income and a negative effect for inflation. The duration variable is intended as a measure of the "rising hazards" of party incumbency. Pollard (1983) and Abramowitz (1988, 1994) both use a dummy variable to represent the desire for a change when a party has been in control for two terms or more. In our view, although personal incumbency is advantageous, party incumbency incurs rising hazards because of what Campbell, et al. $(1960,554)$ call "a negative public reaction to the record of a party in power." The idea is that the longer a party is in control, the more negative outcomes accumulate, 
and, because of the asymmetry between positivity and negativity (see below), the greater the probability of its losing electoral strength. In other words, growing public weariness of a party's control leads to an increasing sentiment that it is "time for a change." Lin (1990, 1993b) discusses these issues.

Equation 1 is distinctive in that all independent variables postulated to have a negative effect are squared. The asymmetric effect between "liking" and "disliking" in attitudinal surveys in general, and between economic "good times" and "bad times" in voting in particular, has been well documented (Jordon 1965; Kanouse and Hanson 1972; Bloom and Price 1975; Kernell 1977; Lau 1985). We use squared independent variables to account for this negativity effect. Since $\frac{\partial\left(\beta X^{2}\right)}{\partial X}=2 \beta X$, squaring an independent variable essentially makes the effect of the variable vary in proportion to the magnitude of the variable. Thus, for a variable with a negative effect, the greater the magnitude (e.g., of inflation or deflation), the greater the negative impact it has on the dependent variable. ${ }^{6}$

Note that, except for incumbency status, this baseline model includes no substantive, political explanatory variables. It is ironic that such a model has been the predominant model for arguably the most interesting dependent variable in the study of aggregate political phenomenon. Into this baseline model we introduce our measure of political corruption $\left(P C_{t}\right)$ :

$$
V_{t}=\beta_{1}+\beta_{2} \cdot P_{t} \cdot I_{t}+\beta_{3} \cdot P_{t} \cdot \Delta D P I_{t}+\beta_{4} \cdot P_{t} \cdot\left(\left|\Delta C P I_{t}\right|\right)^{2}+\beta_{5} \cdot P_{t} \cdot\left(D C_{t}\right)^{2}+\beta_{6} \cdot P_{t} \cdot\left(P C_{t}\right)^{2}+v_{t}
$$

Here $P C_{t}$ is the four-year average of the annual average numbers of corruption-related stories per periodical indexed in the Reader's Guide over a presidential term. The addition of this variable reflects an electorate processing information about political corruption in the same way they evaluate the economic performance of the incumbent party. For the historical period we examine here (1929-1992), we postulate an aggregate negative effect on the vote as a result of such information processing. Following our practice, we take the square of $P C_{t}$ to underscore the asymmetry between positive and negative effects.

In addition to Equation 2, we propose an alternative equation that includes a squared interactive effect between the duration of party control and information about political corruption without main effects from the two variables. The rationale for the interaction term is obvious: the duration variable is effective only when negative outcomes accumulate. Public weariness with a party's policies, when compounded by persistent information about political corruption, is likely to accelerate the desire for a change. Similarly, the electorate's processing of information about political 
corruption is certain to be influenced by the duration of control. The same amount of information is more likely to push the electorate past its tolerance threshold for a third-term incumbency (e.g., Bush's administration) than for a one-term incumbency. Hence Equation 3:

$$
V_{t}=\gamma_{1}+\gamma_{2} \cdot P_{t} \cdot I_{t}+\gamma_{3} \cdot P_{t} \cdot \Delta D P I_{t}+\gamma_{4} \cdot P_{t} \cdot\left(\left|\Delta C P I_{t}\right|\right)^{2}+\gamma_{5} \cdot P_{t} \cdot\left(D C_{t} \cdot P C_{t}\right)^{2}+w_{t}
$$

We first estimate the three equations for the presidential elections from 1932 to 1988, leaving out 1992 for the purpose of an ex post forecast. OLS estimation of all equations provides inconclusive results for the conventional Durbin-Watson autocorrelation test, obviously because of the low degrees of freedom. We follow the conservative practice suggested by Johnston $(1984,316)$ in rejecting the null hypothesis of no autocorrelation. Estimated generalized least squares (EGLS) estimation shows that, although Equation 1 has a relatively good fit $\left(R^{2}=.87\right)$, the inclusion of information about political corruption substantially reduces the standard error of regression, from $2.70 \%$ in Equation 1 to $2.00 \%$ in Equation 2 and 1.85\% in Equation 3. All the coefficients are statistically significant and have the expected signs.

(Table 1 about here)

The estimated coefficient for the corruption term in Equation 2 shows that for an average of one story per periodical during a presidential term, the incumbent party loses more than two points of support in the ensuing election. But the negative effect varies quadratically with the amount of information about corruption. For the estimation period, the average value of $P C_{t}$ is .44 stories per periodical, corresponding to a loss of .44 points of support. In comparison, the Nixon/Ford administration had a $P C_{t}$ of almost two stories per periodical, resulting in a Republican loss of $8.86 \%$ in the 1976 election. Next to this Watergate period, the Bush administration saw the second largest volume of corruption stories; the four-year average is .82 stories per periodical, which leads to a $1.51 \%$ disadvantage.

The Bush presidency, however, was the third consecutive term of Republican control $\left(D C_{t}=3\right)$. As such, it also suffered from the "time for a change" itch. According to Equation 2, the expected Republican loss on this account is 1.38 points. In contrast, the interaction of $D C_{t}$ and $P C_{t}$ in Equation 3 predicts a Republican loss of $3.80 \%$ due to public weariness and political corruption, an amount that is greater than the sum of the two separate main effects predicted by Equation 2. Equation 3 also predicts a 5.18\% incumbency advantage for Bush and an additional 1.17\% support 
contributed by Bush Administration's performance in the economy. At least for 1992, the electoral effect engendered by information about political corruption was more than three times greater than the overall effect from the economy. ${ }^{7}$

Theoretical justifiability and empirical goodness of fit notwithstanding, Equations 2 and 3 do not produce acceptable ex post forecasts for the 1992 election. ${ }^{8}$ Equation 3, the better of the two, predicts a Democratic share of the two-party vote of only $45.1 \%$, substantially smaller than the $53.4 \%$ Clinton actually won. Even considering the forecast error $( \pm 4.6 \%)$, Equation 3 does not predict a Democratic win at the $95 \%$ confidence level. We note, however, that because of the good fit of the models, our forecast errors are small compared with those of other models as reported in Greene (1993). At the $95 \%$ confidence level, a forecast error of $\pm 4.6 \%$ is roughly the same as the percentage sampling error associated with a sample survey of 600-750 respondents. The typical Gallup Survey with a sample size of 1,500 has a sampling error of approximately $\pm 3 \%$. In any case, our equations are not intended for forecasting future elections; values of the substantive independent variables are unknown until after the election. Our purpose is to examine the statistical relevance

of information about corruption to presidential elections. Reestimating the equations for the entire period from 1932 to 1992, the goodness of fit drops, but the results still indicate strong relevance (see Table 2). ${ }^{9}$ Figure 3 compares the predictions of Equation 3 with and without the 1992 election and the actual vote.

(Table 2 about here)

(Figure 3 about here)

The only reservation we have about our models is the advantage credited to the incumbent president running for reelection. For 1932-1988, the advantage is 5.75\% in Equation 2 and 5.18\% in Equation 3, and for 1932-1992, it is 5.28\% and 4.15\%. Examining all the elections since 1932, we find that before Watergate, except for Hoover in 1932, all running incumbents were reelected: Roosevelt in 1936, 1940, 1944; Truman in 1948; Eisenhower in 1956; Johnson in 1964; and Nixon in 1972. After Watergate, however, only Reagan in 1984 won reelection; Ford lost in 1976; Carter in 1980; and Bush in 1992. As is well known, efficacy and trust in government declined markedly in the 1960s and continued to slide after Watergate; although the early 1980s saw a modest rebound of trust, it soon subsided (Aldrich and Niemi 1990, 23). We suspect that the effect of personal incumbency on the presidential vote is correlated with the decline of confidence in government. In turn, we suspect both are also correlated with a sea-change in American politics that altered the 
parameters of the "true" model. This would account for the failure of our model to predict the 1992 election. Our data, however, do not allow us to estimate a time-varying parameter regression model (Lin 1993a). But when we set the effect to zero for post-Watergate elections, the forecast of the 1992 election is substantially improved. For Equation 3, the forecast for Clinton support is $50.31 \%$, with a $95 \%$ confidence band of $\pm 5.96 \%$.

\section{Conclusions}

In this paper we develop a theory of voting according to which a voter rationally incorporates political as well as economic information in his or her vote choice. We have elaborated on the relevance of the historical context in which such a theory is to be found at work. Very often time-series analysis is "ahistoric" because methodological expediency is sought at the expense of historical context. Our empirical findings support our argument about a negative relation between information about corruption and electoral support for the party in control of the presidency. We emphasize that we derive the expectation from our conception of voting behavior as necessarily oriented by the particular historical context in which the voter is situated.

Our conceptualization of corruption as information is consistent with both the liberal and republican views. Actually, with the exception of major scandals involving the president and/or his close associates, the electoral response to information about corruption as we theorize here implies that the public may be dealing with the perceived lack of virtue of public life rather than with specific corrupt behavior. ${ }^{10}$ Whether this is indeed true, of course, requires further tests at the individual level. Our empirical findings, however, do suggest that, to the extent of available information about corruption, the president, or the presidential party, is held responsible. No matter if one accepts a liberal or a republican view, political corruption clearly has consequences for the functioning of the American political system. It is a phenomenon that merits serious inquiry. 


\section{Appendix 1: Data and Sources}

\section{Sources}

1. EROP: Economic Report of the President (1994). United States Government Printing Office.

2. NIPA: The National Income and Product Accounts of the United States, 1929-82 (1986). United States Department of Commerce.

3. HSUS: Historical Statistics of the United States, Colonial Times to 1970 (1976). United States Bureau of the Census.

4. CQ GUIDE: Congressional Quarterly's Guide to U.S. Elections (1985), 2d ed., Washington, D.C.: Congressional Quarterly.

5. RG: Reader's Guide to Periodical Literature. Multiple vols. New York: H.W. Wilson.

\section{Data}

$V_{t}$ : Democratic share of the two-party vote.

The 1932-1984 figures are calculated from data given in CQ GUIDE. The 1988 figure is from Congressional Quarterly Weekly Report, Vol. 47, No. 3 (January 21, 1989). The 1992 figure is based on the Associated Press report of 43,860,888 for Clinton and 38,220,427 for Bush. Only the official candidates of the two major parties are included in the calculation.

$P_{t}$ : Incumbent president's party $(1=$ Democrat,$-1=$ Republican $)$.

$I_{t}$ : Personal incumbency ( 1 if the incumbent president is running, 0 if not). Truman in 1948, Johnson in 1964, and Ford in 1976 are considered as incumbents.

$\triangle D P I$ : Annual growth rate of per capita disposable personal income.

$$
\Delta D P I_{t}=\frac{D P I_{t}-D P I_{t-1}}{D P I_{t-1}} \times 100 \quad(t=1932,1936, \ldots, 1992)
$$

where $\triangle D P I_{t}$, per capita disposable income, is from NIPA (1929-1956, in 1982 dollars) and EROP (1959-1992, in 1987 dollars). 
$\triangle C P I_{t}$ : Annual inflation rate in consumer price indexes for commodities and services, all items $(1982-84=100)$.

The 1940-1992 figures are from EROP. For 1932 and 1936,

$$
\Delta C P I_{t}=\frac{C P I_{t}-C P I_{t-1}}{C P I_{t-1}} \times 100 \quad(t=1932,1936)
$$

where $C P I_{t}$, the consumer price indexes, major expenditure classes, all items $(1982-84=100)$, were taken from HSUS.

$D C_{t}$ : Number of consecutive terms ("duration") of incumbent party control of the presidency.

$P C_{t}$ : Four-year average of the annual average number of corruption-related stories per periodical indexed in the RG over a presidential term. All articles involving U.S. national, state, or local events under the categories "Politics, Corruption in" and "Political Ethics" were counted. In addition, all articles under headings cross-referenced under "Politics, Corruption in" were counted. Over the entire period the RG indexes these categories included the following: "boss rule" or "bossism," "bribery," "campaign funds," "civil service reform," "conflict of interests (public office)," "elections - corrupt practices," "government investigations, congressman," "graft" or "San Francisco - graft and graft prosecution," "lobbying," "misconduct in office," "muckrakers" or "muckraking," "patronage, political," "scandal," "spoils system," "Tammany Hall," "Teapot Dome Case," "US-Congress-House - standards of official conduct," "Abscam," and "Watergate." 


\section{Notes}

${ }^{1}$ Fiorina (1990), for instance, suggests that rationality and information are independent concepts.

${ }^{2}$ Electoral corruption did not die out altogether. Electoral fraud in various forms persisted well into the twentieth century, notably in the South and in machine-dominated cities in the North. Indeed, opportunities for direct manipulation of the vote still exist, witness the braggadocio of Ed Rollins in the 1993 New Jersey gubernatorial election. More insidious, if seldom discussed, opportunities have appeared as the use of computers to record and tally votes expands (Peterson 1993).

${ }^{3}$ We refer to individual rationality, but an argument about collective rationality along the lines Chapell and Keech (1990) suggest with respect to macroeconomic policy can be built on individual rationality. Page and Shapiro's (1992) more holistic view of collective rationality is also consistent with our argument. They argue that, given available information and underlying values, voters' preferences perhaps individually, but more importantly in the aggregate, change in understandable, predictable, and sensible ways. Though they speak of the rational public, their conception of collective rationality invites periodization. If, over time, preferences or responses change as they find in 50 years of public opinion data, we may argue the appropriateness of speaking of rational publics in different historical periods. They do not attempt to periodize opinion, but they make much of what they term "parallel publics" in describing opinion change. Public opinion change, they argue, fits their criteria of collective rationality. As they say:

When aggregate preferences change, especially when they do so over a lengthy period, all segments of the public generally move in the same direction, and usually at about the same rate. Apparently-given our pervasive system of mass communications-important new information usually reaches most groups about equally well, is accepted as about equally credible, is processed with about equal success, and engages common values, thus leading to similar opinion changes (pp. 178-9).

Such long-term, durable opinion changes suggest that, even without opinion data to replicate their study for earlier periods, we may speak of publics in different periods as rational but differing substantively in their aggregate preferences.

${ }^{4}$ Leaders may still dispense material benefits to voters. These, however, generally appear in new forms reflecting the changes we describe. The federal government dispenses disaster relief, student loans, agricultural subsidies, and a host of other benefits to individuals not in exchange for their votes but according to universally applicable formulae.

${ }^{5}$ Iran-Contra stories were first indexed in 1986 under the heading "Iran arms-Contra aid case" which in subsequent years became "Iran-Contra Affair." The article count peaked in 1987 (468) rivaled only by Watergate.

${ }^{6}$ Ideally, we could transform $\triangle D P I_{t}$ into $\Delta D P I_{t}^{\prime}=\log \left(a \cdot \Delta D P I_{t}+b\right)$, where $a$ and $b$ are scaling parameters such that $a>0$ and $a \cdot \Delta D P I_{t}+b>0$, for use as an independent variable in 
the equations. The effect of $\triangle D P I_{t}$ would then be proportional to

$$
\frac{\partial \log \left(a \cdot \Delta D P I_{t}+b\right)}{\partial\left(\Delta D P I_{t}\right)}=\frac{a}{a \cdot \Delta D P I_{t}+b}
$$

which is larger in bad times (i.e., negative or small $\triangle D P I_{t}$ ) than in good times (i.e., positive and large $\left.\triangle D P I_{t}\right)$. Such a transformation, however, adds more parameters and entails nonlinear estimation procedures. Given the small sample size for the historical period we analyze, we opted for the linear functional form specified in our equations.

${ }^{7}$ Given that economy-related issues dominated the 1992 campaign, this result seems surprising. 1992 National Election Study responses to questions about problems facing the country make clear the importance of the economy: domestic, primarily economic, concerns dominated responses. Corruption-related concerns (e.g., honesty, trust, ethics in government) seldom surfaced. Given the substance of information about political corruption in this period, however, this is consistent with our argument for an interaction effect which captures desire for change. Corruption stories from 1989-92 (notably the HUD and S\&L scandals) tended to remind voters of the national economic costs of political corruption. This component of corruption information seems to have reinforced the centrality of economic concerns in the campaign while the negative effect of such information combined with three terms of Republican control of the White House spurred desire for a change.

${ }^{8}$ See Pindyck and Rubinfeld (1991, 190-192) and Judge et al. (1985, 315-318) for calculating the $95 \%$ confidence band in forecasting with serially correlated errors. Judge et al. point out that, because of the use of estimated parameter values, the predictor is not best linear unbiased, and the confidence band does not reflect all the uncertainty in the predictions.

${ }^{9}$ Reestimates of our vote equations in Tables 1 and 2 including Iran-Contra data yielded only mixed improvement. Signs of coefficients remained as expected and all coefficients were significant at the $p \leq .05$ level, but the magnitudes of the effects shifted slightly. Overall, re-estimation of Equation 3 in Table 1 for 1932-1988 produced a lower corrected $R^{2}(.894)$, a higher standard error of regression (2.408), and a higher ex post forecast for 1992 (47.1 \pm 6.1$)$. Re-estimation of Equation 3 in Table 2 for 1932-1992 yielded a slightly higher corrected $R^{2}(.856)$ and a slightly lower standard error of regression (2.730).

${ }^{10}$ We are indebted to Michael Johnston for pointing this out in valuable comments on an earlier version of this paper. 


\section{References}

Abramowitz, Alan I. 1988. "An Improved Model for Predicting Presidential Election Outcomes." $P S$ 21:843-7.

Abramowitz, Alan I. 1994. "Is It Time for Them to Go? Forecasting the 1992 Presidential Election." The Political Methodologist 5(2): 2-3.

Aldrich, John, and Richard G. Niemi. 1990. "The Sixth American Party System: The 1960s Realignment and the CandidateCentered Parties." Papers in American Politics, Working Paper No. 107. Duke University Program in Political Economy.

Allen, Howard W., and Kay Warren Allen. 1981. "Vote Fraud and Data Validity." in Jerome Clubb, William Flanigan, and Nancy Zingale, eds. Analyzing Electoral History: A Guide to the Study of American Voting Behavior. Beverly Hills: Sage.

Banfield, Edward C., and James Q. Wilson. 1963. City Politics. New York: Vintage Books.

Beck, Paul Allen. 1986. "Choice, Context, and Consequence: Beaten and Unbeaten Paths toward a Science of Electoral Behavior." In Political Science: The Science of Politics, ed. Herbert F. Weisberg. New York: Agathon Press.

Bloom, Howard S., and H. Douglas Price. 1975. "Voter Response to Short-Run Economic Conditions: The Asymmetric Effect of Prosperity and Recession." American Political Science Review 69:1240-54.

Bridges, Amy. 1984. A City in the Republic: Antebellum New York and the Origins of Machine Politics. New York: Cambridge University Press.

Burnham, Walter Dean. 1965. "The Changing Shape of the American Political Universe." American Political Science Review 59:7-28.

Burnham, Walter Dean. 1974. "Theory and Voting Research." American Political Science Review 68:1002-23.

Burnham, Walter Dean. 1986. "Those High Nineteenth-Century American Voting Turnouts: Fact or Fiction?" Journal of Interdisciplinary History 16:613-44.

Campbell, Angus, Philip E. Converse, Warren E. Miller, and Donald E. Stokes. 1960. The American Voter, Unabridged ed. Chicago: University of Chicago Press. 
Chapell, Henry W., Jr., and William R. Keech. 1990. "Citizen Information, Rationality, and the Politics of Macroeconomic Policy." In Information and Democratic Processes, eds. John A. Ferejohn and James H. Kuklinski. Urbana, IL: University of Illinois Press.

Cohen, Lizabeth. 1990. Making a New Deal: Industrial Workers in Chicago, 1919-1939. New York: Cambridge University Press.

Converse, Philip E. 1972. "Change in the American Electorate." In The Human Meaning of Social Change. eds. Angus Campbell and Philip Converse. New York: Russell Sage.

Cox, Gary W., and J. Morgan Kousser. 1981. "Turnout and Rural Corruption: New York as a Test Case." American Journal of Political Science 25:646-63.

Davis, Otto A., and Melvin J. Hinich. 1966. "A Mathematical Model of Policy Formation in a Democratic Society." In Mathematical Applications in Political Science II, ed. J. L. Bernd. Dallas: Southern Methodist University Press.

Enelow, James M., and Melvin J. Hinich. 1984. The Spatial Theory of Voting: An Introduction. New York: Cambridge University Press.

Euben, J. Peter. 1989. "Corruption." In Political Innovation and Conceptual Change, eds. Terence Ball, James Farr, and Russell Hanson. New York: Cambridge University Press.

Fair, Ray C. 1978. "The Effect of Economic Events on Votes for President." Review of Economics and Statistics 60:159-172.

Fair, Ray C. 1982. "The Effect of Economic Events on Votes for the President: 1980 Results." Review of Economics and Statistics 64:322-25.

Fair, Ray C. 1988. "The Effect of Economic Events on Votes for President: A 1984 Update." Political Behavior 10:168-79.

Fiorina, Morris P. 1990. "Information and Rationality in Elections." In Information and Democratic Processes, eds. John A. Ferejohn and James H. Kuklinski. Urbana, IL: University of Illinois Press.

Gosnell, Harold F. 1968. Machine Politics: Chicago Model. 2d ed. Chicago: University of Chicago Press.

Greene, Jay P. 1993. "Forewarned before Forecast: Presidential Election Forecasting Models and the 1992 Election." $P S$ 26:17-21. 
Grimshaw, William J. 1992. Bitter Fruit: Black Politics and the Chicago Machine, 1931-1991. Chicago: University of Chicago Press.

Hays, Samuel P. 1967. "Political Parties and the CommunitySociety Continuum." In The American Party Systems: Stages of Development, eds. William Nisbet Chambers and Walter Dean Burnham. New York: Oxford University Press.

Heidenheimer, Arnold, Michael Johnston, and Victor LeVine, eds. 1989. Political Corruption: A Handbook. New Brunswick, NJ: Transaction Publishers.

Inglehart, Ronald. 1990. Culture Shift in Advanced Industrial Society. Princeton: Princeton University Press.

Isaac, Larry W., and Larry J. Griffin. 1989. "Ahistoricism in Time-Series Analyses of Historical Process: Critique, Redirection, and Illustration from U.S. Labor History." American Sociological Review 54:873-90.

Johnston, J. 1984. Econometric Methods, 3rd ed. New York: McGraw-Hill.

Johnston, Michael. 1983. "Corruption and Political Culture in America: An Empirical Perspective." Publius 13:19-39.

Jordan, Nehemiah. 1965. "The 'Asymmetry' of 'Liking' and 'Disliking': A Phenomenon Meriting Further Reflection and Research." Public Opinion Quarterly 29:315-22.

Judge, George G., William E. Griffiths, R. Carter Hill, and Tsoung-Chao Lee. 1985. The Theory and Practice of Econometrics. 2d ed. New York: John Wiley.

Kanouse, David E., and L. Reid Hanson. 1972. "Negativity in Evaluation." In Attribution: Perceiving the Causes of Behavior. eds. Edward E. Jones et al. Morristown, NJ: General Learning Press.

Kernell, Samuel. 1977. "Presidential Popularity and Negative Voting." American Political Science Review 71:44-66.

Lau, Richard R. 1985. "Two Explanations for Negativity Effects in Political Behavior." American Journal of Political Science 29:119-38.

Lewis-Beck, Michael S., and Tom W. Rice. 1992. Forecasting Elections. Washington: CQ Press.

Lin, Tse-min. 1990. "The Equilibrium Cycle in Presidential Elections." Ph.D. diss. University of Minnesota. 
Lin, Tse-min. 1993a. "The Historical Significance of Economic Voting." Presented at the annual meeting of the Midwest Political Science Association, Chicago.

Lin, Tse-min. 1993b. "The Hazards of Party Incumbency in Presidential Elections." Presented at the annual meeting of the American Political Science Association, Washington.

Manheim, Jarol B. 1976. Deja Vu: American Political Problems in Historical Perspective. New York: St. Martin's.

Mayfield, Loomis. 1993. "Voting Fraud in Early Twentieth-Century Pittsburgh." Journal of Interdisciplinary History 24:59-84.

Meier, Kenneth J., and Thomas M. Holbrook. 1992. "'I Seen My Opportunities and I Took 'Em:" Political Corruption in the American States." Journal of Politics 54:135-55.

Merton, Robert. 1957. Social Theory and Social Structure. New York: Free Press.

Nice, David C. 1983. "Political Corruption in the American States." American Politics Quarterly 11:507-17.

Noggle, Burl. 1962. Teapot Dome: Oil and Politics in the 1920s. Baton Rouge: Louisiana State University Press.

Page, Benjamin I., and Robert Y. Shapiro. 1992. The Rational Public: Fifty Years of Trends in Americans' Policy Preferences. Chicago: University of Chicago Press.

Peters, John G., and Susan Welch. 1980. "Effects of Charges of Corruption on Voting Behavior in Congressional Elections." American Political Science Review 74:697-708.

Peterson, Ivars. 1993. "Making Votes Count: How to Steal an Election-the Modern Way." Science News, October 30.

Phillips, Kevin. 1990. The Politics of Rich and Poor: Wealth and the American Electorate in the Reagan Aftermath. New York: Random House.

Pindyck, Robert S., and Daniel L. Rubinfeld. 1991. Econometric Models and Economic Forecasts. 3rd ed. New York: McGrawHill.

Pollard, Walker A. 1983. "Presidential Elections: Cyclical and Distributional Economic Effects." Public FinanceQuarterly 11:217-36.

Riordan, William L. 1994. Plunkitt of Tammany Hall. New York: St. Martin's. 
Rose-Ackerman, Susan. 1978. Corruption: A Study in Political Economy. New York: Academic Press.

Rundquist, Barry S., Gerald S. Strom, and John G. Peters. 1977. "Corrupt Politicians and Their Electoral Support: Some Experimental Observations." American Political Science Review 71:954-63.

Steffens, J. Lincoln. 1931. The Autobiography of Lincoln Steffens. New York: Harcourt.

Wiebe, Robert H. 1967. The Search for Order, 1877-1920. New York: Hill and Wang.

Wolfinger, Raymond E. 1972. "Why Machines Have Not Withered Away and Other Revisionist Thoughts." Journal of Politics 34:365-98.

Woodward, C. Vann, ed. 1974. Responses of the Presidents to Charges of Misconduct. New York: Dell Publishing. 
Figure 1. Average Number of Corruption Stories Per Periodical, 1890-1992

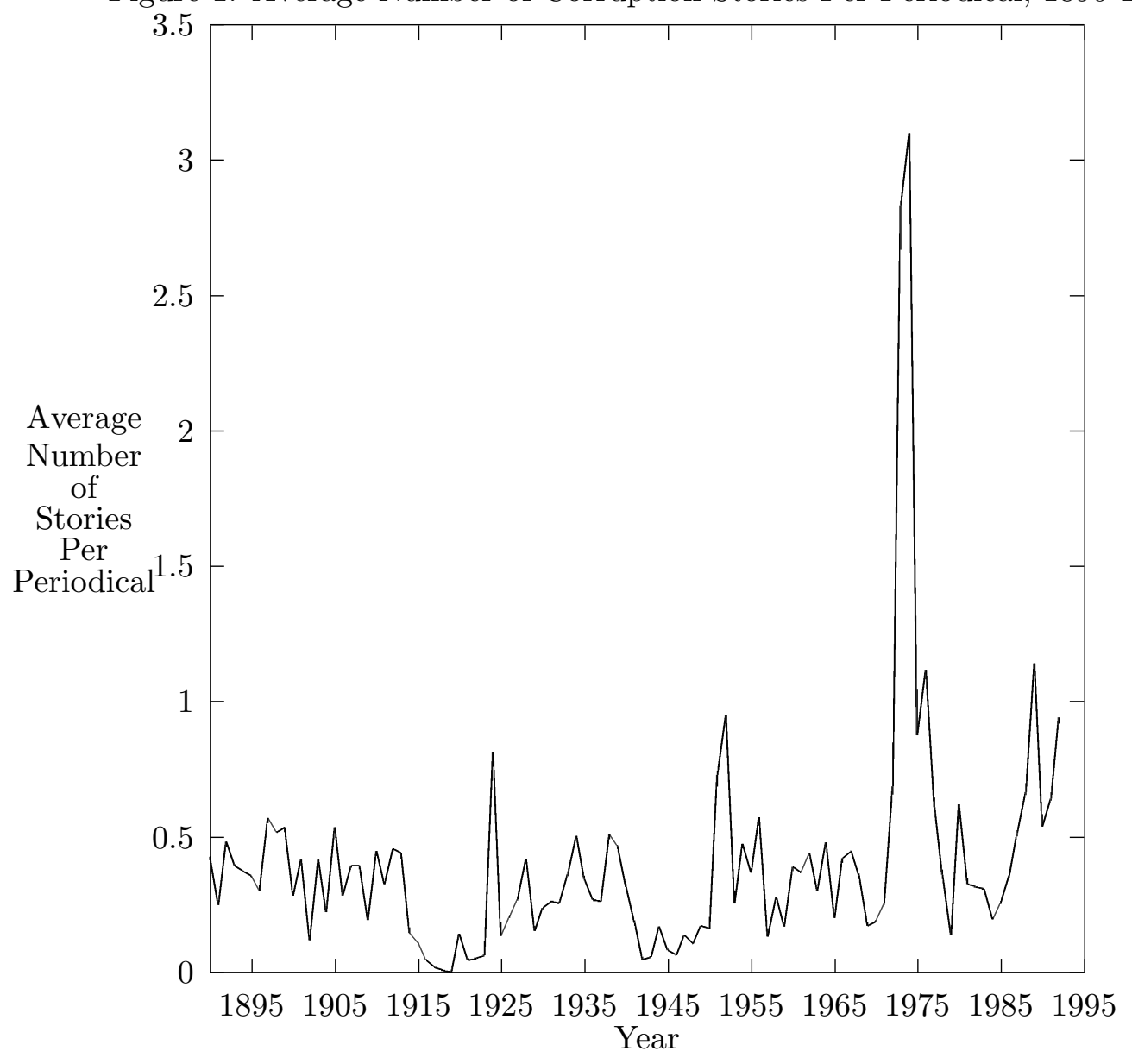


Figure 2. Moving Correlations between Information about Corruption

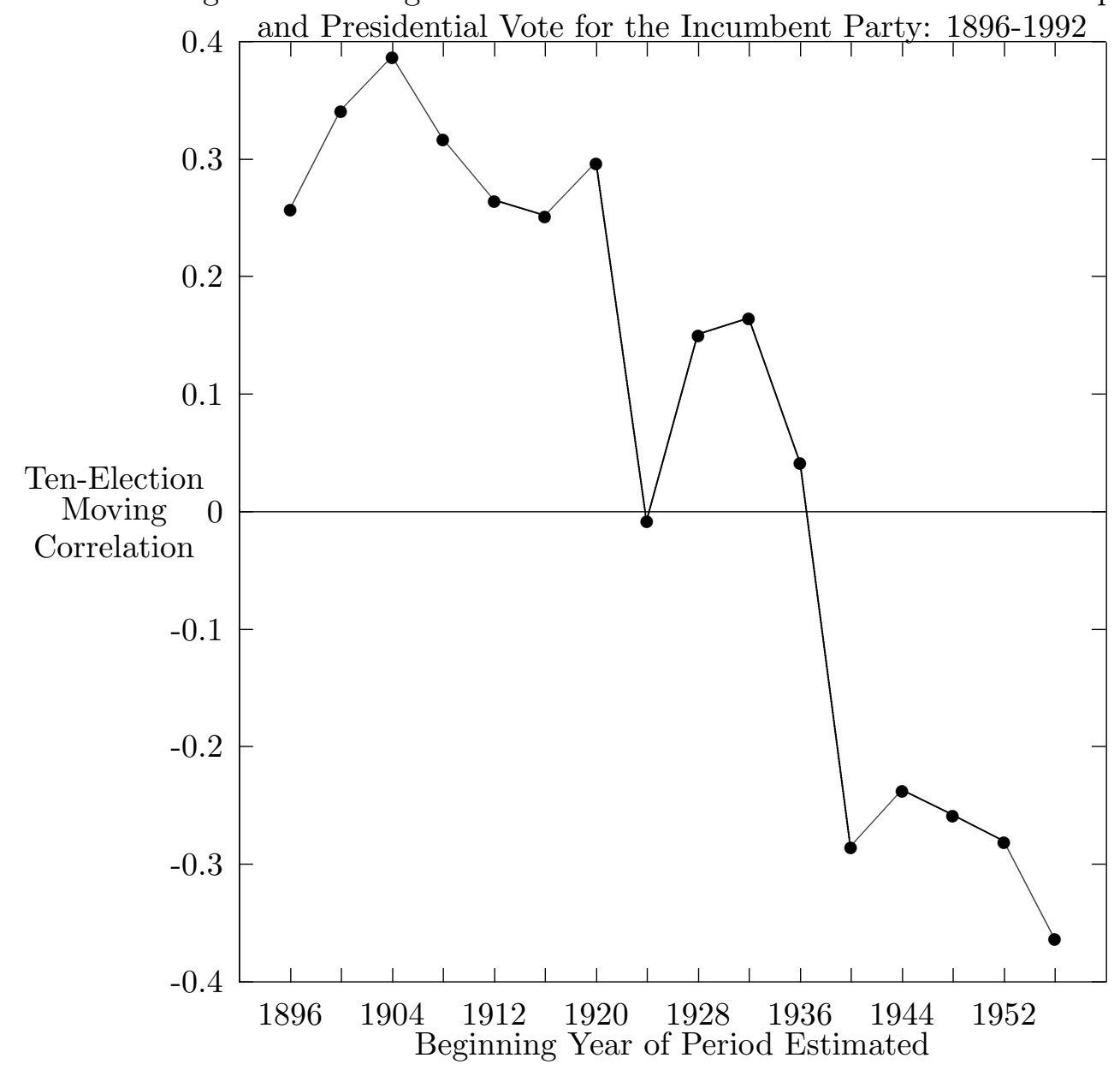


Figure 3. Democratic Share of the Two-Party Vote: 1932-1992

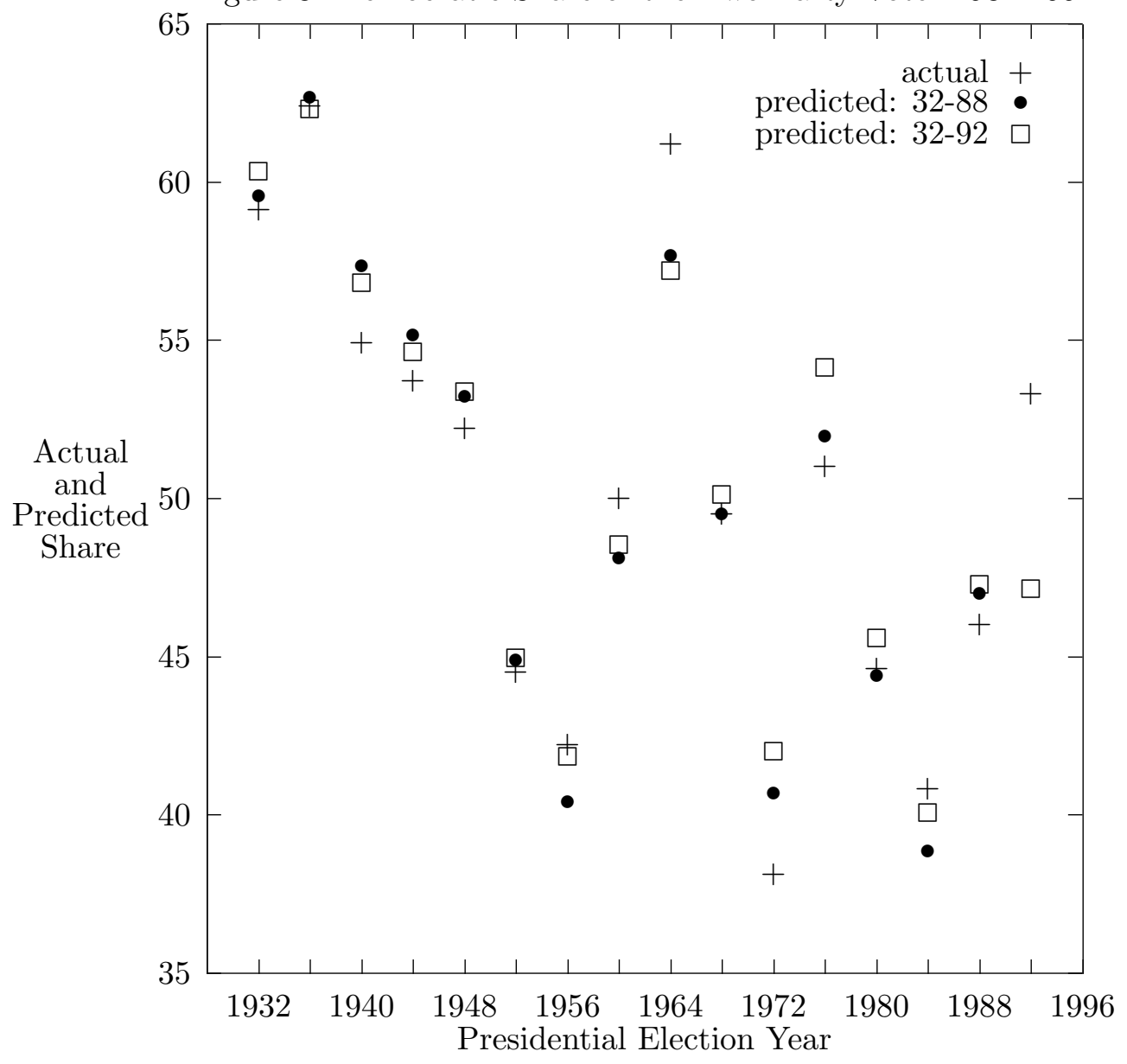


Table 1: Coefficient Estimates for the Vote Equations, Presidential Elections, 1932-1988

\begin{tabular}{|c|c|c|c|}
\hline Variable & Equation 1 & Equation 2 & Equation 3 \\
\hline \multirow[t]{2}{*}{ Intercept } & $49.096^{* *}$ & $48.202^{* *}$ & $47.900^{* *}$ \\
\hline & $(0.678)$ & $(0.696)$ & $(0.741)$ \\
\hline \multirow[t]{2}{*}{ Personal Incumbency } & $5.002^{* *}$ & $5.748^{* *}$ & $5.182^{* *}$ \\
\hline & $(1.247)$ & $(1.032)$ & $(0.917)$ \\
\hline \multirow[t]{2}{*}{ Per capita income growth } & $0.744^{* *}$ & $0.820^{* *}$ & $0.866^{* *}$ \\
\hline & $(0.167)$ & $(0.139)$ & $(0.131)$ \\
\hline \multirow[t]{2}{*}{ CPI inflation/deflation } & $-0.037^{* *}$ & $-0.044^{* *}$ & $-0.046^{* *}$ \\
\hline & $(0.018)$ & $(0.014)$ & $(0.012)$ \\
\hline \multirow[t]{2}{*}{ Duration of party control } & $-0.207^{* *}$ & $-0.153^{* *}$ & \\
\hline & $(0.082)$ & $(0.073)$ & \\
\hline \multirow[t]{2}{*}{ Political Corruption } & & $-2.258^{* *}$ & \\
\hline & & $(0.586)$ & \\
\hline (Duration of party control) & & & $-0.633^{* *}$ \\
\hline x (Political corruption) & & & $(0.113)$ \\
\hline Number of observations & 15 & 15 & 15 \\
\hline Adjusted $R^{2}$ & 0.867 & 0.927 & 0.938 \\
\hline Standard error of regression & 2.704 & 2.007 & 1.845 \\
\hline Ex post forecast for 1992 & $43.6 \pm 7.8$ & $42.9 \pm 5.5$ & $45.1 \pm 4.6$ \\
\hline
\end{tabular}

Source: See Appendix 1.

${ }^{* *} p \leq .05$, one-tailed test. 
Table 2: Coefficient Estimates for the Vote Equations, Presidential Elections, 1932-1992

\begin{tabular}{llll} 
Variable & Equation 1 & Equation 2 & Equation 3 \\
\hline Intercept & $49.651^{* *}$ & $49.067^{* *}$ & $48.329^{* *}$ \\
& $(0.730)$ & $(0.904)$ & $(0.930)$ \\
Personal Incumbency & $4.941^{* *}$ & $5.276^{* *}$ & $4.153^{* *}$ \\
Per capita income growth & $(1.445)$ & $(1.541)$ & $(1.348)$ \\
& $0.695^{* *}$ & $0.761^{* *}$ & $0.884^{* *}$ \\
CPI inflation/deflation & $(0.193)$ & $(0.205)$ & $(0.193)$ \\
& $-0.038^{*}$ & $-0.040^{* *}$ & $-0.036^{* *}$ \\
Duration of party control & $(0.021)$ & $(0.021)$ & $(0.019)$ \\
Political Corruption & $-0.259^{* *}$ & $-0.227^{* *}$ & \\
& $(0.091)$ & $(0.102)$ & \\
(Duration of party control) & & $-1.817^{* *}$ & \\
x (Political corruption) & & $(0.924)$ & $(0.176)$ \\
Number of observations & & & 0.843 \\
Adjusted $R^{2}$ & 16 & 16 & 2.853 \\
Standard error of regression & 3.182 & 0.811 & \\
\hline
\end{tabular}

Source: See Appendix 1.

${ }^{*} p \leq .10$, one-tailed test.

${ }^{* *} p \leq .05$, one-tailed test. 